\title{
Szintlépés vagy átmenet? Az Identitás és Demokrácia képviselőcsoport az Európai Parlamentben
}

Levelling or Transition?

The Identity and Democracy Group in the European Parliament

Hajdú András

https://doi.org/10.47707/Kulugyi_Szemle.2020.3.01

Összefoglaló: A tanulmány a 2019-ben tartott európai parlamenti választást követően alakult radikális jobboldali, Identitás és Demokrácia (ID) nevú képviselőcsoportot hasonlítja össze az intézmény többi frakciójával, továbbá a radikális jobboldal korábbi európai együttmúködési formáival. A képviselők szociodemográfiai jellegzetességeinek és politikai karrierútjának elemzése révén mutatja be az írás a frakció profilját és politikai jelentőségét. A tanulmány célja az ID frakció jellegzetességeinek ismertetésén túl, hogy az új politikai szövetséget elhelyezze a radikális jobboldali pártok együttmúködésének és az európai pártrendszerek átalakulásának a folyamatában.

Kulcsszavak: Identitás és Demokrácia, Európai Parlament, radikális jobboldali pártok

Abstract: This study compares the radical right-wing fraction, the Identity and Democracy (ID) group, which was formed in the European Parliament (EP) after the election in 2019, with the other groups of the EP, as well as with the former European cooperation frames of the radical rightwing parties. The profile and political significance of the ID group is presented by the analysis of the socio-demographic character and the career path of its MEPs. In addition to the analysis of the characteristics of the ID group, the study aims to define the new political alliance in the process of cooperation between radical right-wing parties and the transformation of European party systems.

Keywords: Identity and Democracy, European Parliament, radical right-wing parties

\section{Bevezetés}

Az elmúlt évben Magyarországon is kiemelt figyelem irányult az Európai Parlament (EP) képviselőinek a megválasztására, ami hozzájárult a korábbi választásokon regisztráltnál magasabb részvételhez. Az EP iránti érdeklődés egyik központi kérdése az volt, hogy milyen méretú és tagságú képviselőcsoportot tudnak létrehozni az európai integráció irányával kritikus jobboldali pártok. Bár úgy tűnik, a radikális jobboldali pártok tartós és megkerülhetetlen szereplői lettek az európai politikai életnek (Von Beyme, 2019), a választást követően a magyar szakirodalomban - elsősorban azért, mert mạvar képviselők nem kerültek ilven ideolóaiáiú képviselőcsoportba - 
korlátozott érdeklődés irányult az Identitás és Demokrácia (Identitiy and Democracy, ID) frakcióra. A tanulmány célja az új frakció jellegzetességeinek a bemutatása, valamint a radikális jobboldali pártok együttmúködésének és az európai pártrendszerek átalakulásának a folyamatában történő elhelyezése.

\section{A kutatás tárgya}

A politikai publicisztika, a politikatudomány és a politikai gyakorlat világában egyaránt évtizedeken át élt az az elképzelés, hogy a radikális jobboldali pártok hosszú távon képtelenek hatékony és stabil nemzetközi együttmúködést kialakítani. Ennek igazolásaként gyakran hozták fel példaként az Európai Parlamentet, ahol az egyre hangsúlyosabb szerepük (Ladrech, 2012) ellenére 1994-től a 2010-es évekig csupán egyetlen, rövid életű frakciót (Identitás, Hagyomány, Szuverenitás, Identity, Tradition and Sovereignty, ITS) tudtak létrehozni (Mudde, 2007, 172-181. o.; Almeida, 2010; Startin, 2010).

2013 őszén azonban a korábban elsősorban intézményi kényszerek és egyéni ambíciók által motivált együttmúködési kísérleteket új, tudatos stratégia váltotta fel. Az egymás társaságát addig ideológiai és stratégiai indokokkal elutasító francia Marine Le Pen (Nemzeti Front, Front national, FN) és holland Geert Wilders (Szabadságpárt, Partij voor de Vrijhejid, PVV) egy hágai találkozót követően új európai szövetség létrehozását hirdette meg, amely a célkitúzésük szerint az európai integráció és a bevándorlás ellen kíván fellépni (Hajdú, 2017a, 74-75. o.). Bár az együttmúködéshez több párt - az Osztrák Szabadságpárt (Freiheitliche Partei Österreichs, FPÖ), az olasz Északi Liga (Lega Nord, LN), a belga Flamand Érdek (Vlaams Belang, VB) - is csatlakozott, a 2014-es európai parlamenti választást követően még nem sikerült frakciót alakítaniuk. Ez ismét azon elmélet igazolásának tűnt, miszerint az ilyen típusú pártok nem tudnak széles és hatékony nemzetközi együttműködést megteremteni (Mudde, 2014b).

2015 júniusában azonban egy lengyel párt, az Új Jobboldali Kongresszus (Kongres Nowej Prawicy, KNP), valamint egy addig független brit képviselő csatlakozásával megalakult a Nemzetek és Szabadság Európája (Europe of Nations and Freedom, ENF) képviselőcsoport, amely a radikális jobboldal korábbi európai együttmúködéseinél szélesebbnek és látványosabbnak bizonyult (Hajdú 2017a,75-79. o.). A frakció mögött álló euroszkeptikus európai parlamenti párt (a továbbiakban: europárt), a Mozgalom az Európai Nemzetekért és Szabadságért (Movement for a Europe of Nations and Freedom, MENF), a 2019-es EP-választásra új tagokkal bővült, és a mostani ciklusra még népesebb frakció létrehozását hirdette meg célként. Ez a választást követően az Identitás és Demokrácia képviselőcsoport létrehozását eredményezte. Az ID 1994 óta az első radikális jobboldali frakció, amelynek már az EP alakuló ülésére sikerült megalakulnia, egyúttal az ENF-nél is szélesebb szövetséget képez. 


\section{Külügyi Szemle}

A jelen tanulmány célja az Identitás és Demokrácia frakció bemutatása, valamint a politikai jelentőségének az elemzése. Mivel a választási eredmények értékelése gyakran a politikai szimpátia és az érdekek alapján történik, ezért annak megítélése érdekében, hogy az ID milyen politikai erőt képvisel, statisztikai adatokat és a képviselők karrierjét fogom elemezni. A frakció összetétele, mérete, az érintett pártok választási eredményei és kormányzati szerepe/potenciálja mellett azt is figyelembe veszem, hogy kik azok a politikusok, akik 2019-ben mandátumot szereztek. A képviselők szolgálati ideje, politikai karrierútja, neme és életkora mentén fogom a frakciót az EP más képviselőcsoportjaival, továbbá a korábbi radikális jobboldali frakciókkal összehasonlítani. A tanulmány során a vizsgálandó pártok euroszkepticizmusát adottnak tekinti, ezért az nem számít kutatási kérdésnek.

\section{A radikális jobboldal az Európai Parlamentben}

A politikai és politikatudományi vitákban egyaránt visszatérő kérdés, hogy miért akar a radikális jobboldal egyáltalán szervezett együttmúködést egy olyan intézményben, amely olyan projektet szolgál, amit az érintett pártok évtizedek óta elutasítanak. Az egyik válasz lehetőségét az intézményi környezet kínálja. Az EP múködése, más modern törvényhozó testületekéhez hasonlóan, képviselőcsoportokra épül (Hix, Noury, Abdul G. és Roland, 2007), ezért a függetlenstátusz számos szempontból (pl. kapcsolatok kialakítása, érdekérvényesítés, elérhető patronázspozíciók, felszólalási időkeret) hátrányt jelent (Archick és Mix, 2011; Wagner, 2011). Ez különösen azon szereplők számára bír ösztönző erővel, akik a hazai színtéren nem, vagy csak korlátozottan rendelkeznek parlamenti képviselettel (pl. a 2018-ban nevet váltott FN, amely az új neve Nemzeti Tömörülés, Rassemblement national, RN), illetve a pártrendszer peremén, elszigetelődve esélytelenek a kormányzati szerepvállalásra (pl. VB).

Egy másik válaszlehetőséget kínál a képviselők szerepfelfogása. Vannak olyan EPképviselők, akik a saját szerepüket, politikai felhatalmazásukat úgy értelmezik, hogy az európai integrációt ellenző véleményeknek adjanak hangot az intézményben (Brack, 2013, 156-160. o.). Ez az érv különösen hangsúlyosan jelent meg a Nigel Farage vezette Egyesült Királyság Függetlenségi Pártja (UK Independence Party, UKIP), majd a 2019-es EP-választásra szervezett Brexit Párt (Brexit Party) kommunikációjában.

Az elmúlt évtized a két szemlélet összefonódásaként értelmezhető a radikális jobboldali pártok esetében. A közvetlen EP-választás 1979-es bevezetése óta az Európai Néppárt (European People's Party, EPP) a jobboldal egyetlen stabil frakciója, ami elsősorban a széles körú tagságából, valamint a tagok nagyarányú kormányzati pozíciójából ered. Az EPP-tól jobbra ciklusonként újabb és újabb konzervatív, nacionalista, euroszkeptikus és/vagy radikális jobboldali frakciók szerveződtek, amelyek jóval kisebbek, ideológiai és közpolitikai szempontból egyaránt heterogének, tagság szempontjából pedig instabilak 
voltak (Wagner, 2011). Ennek hátterében a jobboldalnak az európai színtéren megfigyelhető fragmentáltsága (Ennser, 2012), valamint a pártokat elválasztó ideológiai, történeti és stratégiai ellentétek, továbbá a pártvezetők személyes rivalizálása áll (Hajdú, 2017a, 64-70. o.). A 2009-es EP-választással kezdődően fokozatos átalakulás érzékelhető az EP-frakciók szerveződésében. Az európai integrációval és elittel szemben állók felismerték, hogy az intézményi környezetből adódó lehetőségeket a saját céljaik szolgálatába állíthatják, ha az európai színtéren szervezettebben lépnek fel; az uniós intézmények logikájához illeszkedő kooperáció pedig a hazai politikában is erőforrássá transzformálható.

Az 1984-ban szerveződött Európai Jobboldal (European Right, ER) frakció még csak egy szűk kört fogott össze, amely nem tudta hatékonyan koordinálni az 1980-as és 1990-es évek fordulóján tapasztalt radikális jobboldali első hullám szereplőit. Az FN számára azonban központi szerepet biztosított a további együttműködési kísérletekhez, emellett segített stabilizálni a párt külföldi kapcsolati hálóját. Az EU keleti bővítésének a második, 2007-es fázisa teremtett ismét frakcióalapítási lehetőséget az FN vezette szövetségi kör (Európai Nemzeti Unió, European National Union, EuroNat) számára, amit az a posztkommunista térségben az 1990-es évek elejétől épített kapcsolatokra alapozva ki is tudott használni - így jött létre az ITS frakció. Ám az a román képviselők távozása miatt - ugyanis a létszám a frakcióstátuszhoz szükséges minimális 20 fő alá csökkent - egy éven belül felbomlott. Mivel azonban a Nagy-Románia Párt (Partidul România Mare, PRM) 2007 novemberében valamennyi EP-mandátumát elveszítette, a kilépésük csak néhány héttel hozta előre a képviselőcsoport megszúnését.

A radikális jobboldali pártok európai együttműködésében a 2010-es évtized kezdete, a Nemzeti Frontban lezajlott generáció- és stratégiaváltás, valamint Geert Wilders hollandiai elszigetelődése hozott változást. Az új kooperáció eredménye lett a 2015-ben alakult ENF frakció (Hajdú 2017a, 71-75. o.).

\section{Az Identitás és Demokrácia képviselőcsoport}

Az ENF frakciónak a 2019-es EP-választáson újra mandátumot szerzett szereplői az új csatlakozókkal közösen Identitás és Demokrácia néven alakítottak képviselőcsoportot. (A ciklus elején történő névváltoztatás nem példa nélküli az EP-frakciók történetében, de különösen a kisebb jobboldaliakra, euroszkeptikusokra jellemző.) ${ }^{1}$ Az új elnevezéshez igazodva a MENF is hivatalos nevet változtatott: Identitás és Demokrácia

1 A UKIP által dominált frakciók például a Függetlenség és Demokrácia (Independence/ Democracy, Ind/Dem; 2004-2009), a Szabadság és Demokrácia Európája (Europe of Freedom and Democracy, EFD; 2009-2014), majd a Szabadság és Közvetlen Demokrácia Európája (Europe of Freedom and Direct Democracy, EFDD; 2014-2019) nevet viselték. Miközben az elnevezés és a tagság ciklusról ciklusra átalakult, a frakció euroszkeptikus programja lényegében változatlan maradt. 


\section{Külügyi Szemle}

Párt (Identity and Democracy Party, ID Party) lett. Ez azonban csak formai módosítást jelentett, hiszen az új europárt átvette az elődje programját, digitális kommunikációs felületeit, s még elnöksége személyi összetétele is változatlan maradt.

Az újjáalakulást kiemelt nemzetközi érdeklődés övezte, ami nem elválasztható attól, hogy a korábbi évek eseményei (pl. a görög válság hatása az eurózónára, a migrációs krízis, a 2016-os brit népszavazás) miatt az uniós elit a 2019-es EP-választásra kockázatként, a radikális jobboldali pártok pedig áttörési lehetőségként tekintettek. A frakció összetételének, méretének, a politikusok karrierútjának, szociodemográfiai jellemzőinek (nem, kor) elemzését követően fogok válaszolni arra a kérdésre, hogy pontosan mi is a politikai relevanciája az ID frakciónak.

\section{A frakció összetétele és mérete}

A 2019-es EP-választási kampány egyik újdonsága volt, hogy a radikális jobboldal az EP-frakciójára és az akkori pártjára (MENF) támaszkodva jelentős európai kampánytevékenységet folytatott, amelyben különösen a francia politikusok voltak aktívak. Bár Marine Le Pen inkább a 2017-es francia nemzetgyúlési választáson megszerzett mandátumát választotta, és 13 év után távozott az EP-ből, továbbra is aktív maradt az európai színtéren. A 2019-es kampányban járt Brüsszelben, Koppenhágában, Szófiában, Pozsonyban és Tallinnban, hogy a helyi szövetséges pártokat segítse, továbbá felszólalt a pártszövetség más meghatározó politikusai (pl. Matteo Salvini, Gerolf Annemans, Geert Wilders) társaságában a prágai és a milánói nagygyúlésen is. Le Pent több helyszínre (Pozsony, Tallinn, Milánó) elkísérte Nicolas Bay - 2017-2019 között Le Pen utódja az ENF társ-frakcióvezetői tisztségében -, aki a kampány utolsó hetében önállóan Horvátországba is elutazott.

Marine Le Pen az apja (Jean-Marie Le Pen) által az 1990-es években követett stratégiája (Mudde 2007, 174-177. o.) alapján a kisebb, keleti tagállamokból igyekezett új pártokat bevonni az együttmúködésbe. Így lett a MENF tagja a nemzeti parlamenti képviselettel már rendelkező cseh Szabadság és Közvetlen Demokrácia (Svoboda a př́má demokracie, SPD), a bolgár Akarat (Volja), a szlovák Család Vagyunk (Sme Rodina, SR) és az Észt Konzervatív Néppárt (Eesti Konservatiivne Rahvaerakond, EKRE). Ezzel párhuzamosan az Olaszországban 2018 tavaszától a populista 5 Csillag Mozgalommal (Movimento 5 Stelle, M5S) közösen kormányzó Liga (az LN utódja), valamint a kormányzati tapasztalattal rendelkező más pártokkal történő együttmúködésről tárgyalt. Ennek eredménye lett az Alternatíva Németországért (Alternative für Deutschland, AfD), a 2015-2017 között kormányzó Igaz Finnek (Perussuomalaiset, PS) (Dúró, 2020 kézirat) és a több cikluson át a kisebbségi jobboldali kormányoknak parlamenti többséget biztosító, „kvázi kormánypárti” szerepet betöltő Dán Néppárt (Dansk Folkeparti, DF) (Polgár 2011, 100-101. o.) csatlakozása. 
A frakció létszáma 2020 februárjában megnövekedett, mert az Egyesült Királyság kilépését követően a mandátumai egy részét újraosztották. Az RN és a Liga mellett az eredetileg mandátum nélkül maradt PVV szerzett 1-1 helyet. Az 1. táblázat jelzi ezt a változást, a tanulmány azonban a továbbiakban csak a választást követően, 2019-ben alakult frakció tagjaira vonatkozik, a 2020-as létszámnövekedés érdemi változásokat nem eredményezett.

\section{1. táblázat ${ }^{2}$}

A radikális jobboldali képviselőcsoportokat alkotó pártok a frakciók alakulásakor

\begin{tabular}{|c|c|c|c|c|c|c|c|}
\hline Ország & Párt & $\begin{array}{c}\text { ER } \\
1984-1989\end{array}$ & $\begin{array}{c}\text { DR } \\
1989-1994\end{array}$ & $\begin{array}{c}\text { ITS } \\
2007\end{array}$ & $\begin{array}{c}\text { ENF } \\
2015-2019\end{array}$ & \multicolumn{2}{|c|}{$\begin{array}{c}\text { ID } \\
2019(/ 2020)-\end{array}$} \\
\hline Ausztria & FPÖ & - & - & 1 & 4 & 3 & 3 \\
\hline Belgium & VB & - & 1 & 3 & 1 & 3 & 3 \\
\hline Bulgária & Ataka & - & - & 1 & - & - & - \\
\hline Csehország & SPD & - & - & - & - & 2 & 2 \\
\hline Dánia & DF & - & - & UEN & ECR & 1 & 1 \\
\hline Észtország & EKRE & - & - & - & - & 1 & 1 \\
\hline Finnország & PS & - & - & - & ECR & 2 & 1 \\
\hline Franciaország & $\mathrm{FN} / \mathrm{RN}$ & 10 & 10 & 7 & 21 & 22 & 23 \\
\hline Görögország & EPEN & 1 & - & - & - & - & - \\
\hline Hollandia & PVV & - & - & - & 4 & - & 1 \\
\hline \multirow[b]{2}{*}{ Németország } & REP & - & 6 & - & - & - & - \\
\hline & AfD & - & - & - & $\begin{array}{c}\text { ECR } \\
\text { EFDD, ENF }\end{array}$ & 11 & 11 \\
\hline Lengyelország & KNP & - & - & - & 2 & - & - \\
\hline \multirow{4}{*}{ Olaszország } & $\mathrm{MSI}$ & 5 & $\mathrm{NI}$ & - & - & - & - \\
\hline & AS & - & - & 1 & - & - & - \\
\hline & FT & - & - & 1 & - & - & - \\
\hline & LN/Liga & - & Szivárvány & UEN & 5 & 28 & 29 \\
\hline Románia & PRM & - & - & 5 & - & - & - \\
\hline \multicolumn{2}{|c|}{ Független képviselők } & 0 & 0 & 1 & 1 & 0 & 0 \\
\hline \multicolumn{2}{|c|}{ Összlétszám az alakuláskor } & 16 & 17 & 20 & 38 & 73 & 76 \\
\hline \multicolumn{2}{|c|}{ Testületen belüli arány } & $3,7 \%$ & $3,3 \%$ & $2,6 \%$ & $5,7 \%$ & $9,7 \%$ & $10,8 \%$ \\
\hline
\end{tabular}

ECR: Európai Konzervatívok és Reformerek.

Korábban az FN kiemelkedő szerepet töltött be a radikális jobboldali pártok között. Bár támogatottság tekintetében akadtak „versenytársai”, azok Franciaországnál jóval kisebb államokban érték el a sikereiket (pl. Ausztria, Belgium, Románia). Az ID frakcióban viszont ma már nem a francia képviselők alkotják a legnagyobb nemzeti delegációt, 2 Forrás: European Parliament, 2020. 


\section{Külügyi Szemle}

és ez az első eset, hogy egy másik nagy EU-tagállam kiemelkedő támogatottságú, az EP-választáson szintén győzelmet aratott párttal közös képviselőcsoportot alkot. Ezt a helyzetet a párt pragmatikusan kezelte, és a frakcióvezetói tisztséget átengedte a Ligának (Marco Zanninak).

További jelentős változás az északi pártok (DF és PS, illetve a profil szempontjából szintén közéjük sorolható észt EKRE) jelenléte az együttmúködésben, hiszen korábban azok határozottan elzárkóztak bármilyen közös platformtól, amely az FN-hez és a hozzá hasonló pártokhoz kötötte volna őket. A csatlakozásuk azért volt hangsúlyos, mert erősitette a Le Pen és Wilders által kezdeményezett együttmúködés legitimációs erejét (Hajdú 2017a, 76-77. o.), amelynek lényege, hogy olyan pártok vesznek benne részt, amelyek vagy kiemelkedő választási eredményeket tudnak felmutatni, vagy elfogadott, legitim partnernek számítanak a nemzeti politikai rendszerükben. Így az ID frakció nem csupán az együttmúködési készség, de a politikai erő felmutatását is jelenti. Ezzel párhuzamosan azonban a szövetség továbbra is elhatárolja magától a legradikálisabb szereplőket (mint a görög Arany Hajnal vagy a Kotleba - Mi Szlovákiánk Néppárt). 2014 előtt a saját pártrendszerük perifériájára került szereplók vettek részt az FN által vezetett együttmúködési projektekben, de ez a helyzet az ENF és az ID frakció keretében megváltozott.

\section{Szolgálati idő}

A 2019-es EP-választás a képviselők tapasztalata és elóélete szerint is jelentős határnak tekinthető. A mandátumot szerzett képviselők közül 435 fő, a képviselők jóval több mint fele számított "újoncnak". Az Európai Néppárt volt az egyetlen frakció, amely esetében az új képviselők aránya 50 százalék alatt maradt. A legmagasabb arány az ID-ben mutatkozott: a 73 fős frakció 81 százaléka töltötte be első ízben a mandátumát (European Parliament Research Service Blog, 2019).

\section{2. táblázat ${ }^{3}$}

Az új EP-képviselők aránya a 2019-es választást követően alakult új frakciókban

\begin{tabular}{|l|c|c|}
\hline \multicolumn{1}{|c|}{ Frakció } & Létszám & Új képviselök aránya \\
\hline EPP & 182 & $41 \%$ \\
\hline S\&D & 154 & $51 \%$ \\
\hline RE & 108 & $69 \%$ \\
\hline Zöldek/EFA & 74 & $69 \%$ \\
\hline ID & 73 & $81 \%$ \\
\hline ECR & 62 & $58 \%$ \\
\hline GUE/NGL & 41 & $59 \%$ \\
\hline NI & 54 & $72 \%$ \\
\hline
\end{tabular}

3 Forrás: European Parliament Research Service Blog, 2019. 
Az intézményi tapasztalat még korlátozottabb, ha figyelembe vesszük, hogy a továbbszolgáló képviselők közül többen is az előző ciklus során vették át a mandátumukat. 2017-ben Jörg Meuthen (AfD) a német, France Jamet (RN) a francia, 2018-ban Oscar Lancini (Liga) az olasz parlamenti választást követően vett át mandátumot hazatérő politikustól. Az EP-ben eltöltött idő alapján a Liga politikusa, Mara Bizzotto a frakció legtapasztaltabb képviselője, aki 2019-ben a harmadik ciklusát kezdte. Társaihoz hasonlóan azonban ő sem viselt magasabb tisztséget - bizottsági vagy plenáris szinten - az intézményben. 2009-2014 között az Ausztráliával és Új-Zélanddal fenntartott kapcsolatokért felelős küldöttség vezetője volt. Amióta az ENF, illetve az ID frakció létrejött, annak tagjaival szemben a többségben lévő mainstream frakciók „politikai karantént" (cordon sanitaire) alkalmaznak. Emiatt a hosszabb szolgálati idővel rendelkező képviselők sem reménykedhetnek jelentősebb befolyással járó intézményi pozíció betöltésében.

\section{3. táblázat ${ }^{4}$}

A radikális jobboldali frakciók képviselőinek szolgálati ideje az Európai Parlamentben

\begin{tabular}{|c|c|c|c|c|c|}
\hline Ciklusok & $\begin{array}{c}\text { ER } \\
1984 \\
(\mathrm{~N}=16)\end{array}$ & $\begin{array}{c}\text { DR } \\
1989 \\
(\mathrm{~N}=17)\end{array}$ & $\begin{array}{c}\text { ITS } \\
2007 \\
(\mathrm{~N}=20)\end{array}$ & $\begin{array}{c}\text { ENF } \\
2015 \\
(\mathrm{~N}=38)\end{array}$ & $\begin{array}{c}\text { ID } \\
(\mathrm{N}=73)\end{array}$ \\
\hline 1. ciklus & 11 & 13 & 12 & 32 & 59 \\
\hline 2. ciklus & 5 & 4 & 3 & 3 & 13 \\
\hline 3. ciklus & 0 & 0 & 2 & 2 & 1 \\
\hline 4. ciklus & 0 & 0 & 2 & 1 & 0 \\
\hline 5. ciklus & 0 & 0 & 1 & 0 & 0 \\
\hline
\end{tabular}

Politikai tapasztalat és karrier

A képviselők egyéni, személyes karrierje és a befolyás szempontjából az 1989-1994 között létezett Európai Jobboldal Technikai Csoportja (Technical Group of the European Right), valamint az ENF frakció kezdeti időszaka volt kiemelkedő. Az előbbiben részt vevő három párt mindegyik alapító elnöke - Karel Dillen (VB), Franz Schönhuber (REP) és Jean-Marie Le Pen (FN) - képviselői mandátummal rendelkezett; az utóbbi egyben a frakcióvezetői tisztséget is betöltötte. Ugyanis akkoriban sem az FN, sem a REP nem rendelkezett a nemzeti parlamentben mandátummal, a VB esetében pedig elkezdődött a Dillen támogatásával zajló radikális fiatalítás (Operation Rejuvenation), amelynek keretében ő maga a párt irányítását fiataloknak (Gerolf Annemans, Filip Dewinter) adta át, s az EP-be távozott (Mudde, 2000, 88. o.). A nemzeti parlamenti képviselet hiánya miatt EP-mandátummal rendelkeztek az FN működtetésében kulcsszerepet betöltő politikusok (Bruno Gollnisch, Bruno Mégret) és a párt szubkulturális gyökereit megjelenítő,

4 Forrás: European Parliament, 2020. 
egy-egy speciális társadalmi csoportot (pl. az ortodox katolikusokat) mozgósítani képes személyek (pl. Bernard Antony, Martine Lehideux) is (Hajdú, 2017b, 16. o.).

A 2014-ben kezdődött ciklus első szakaszában szintén számos, a saját pártjában és a nemzeti politikai rendszerben meghatározó személyiségnek tekintett radikális jobboldali politikus volt EP-képviselő. Ez az évtized elején lezajlott elnök- és generációváltás következtében történt. Az FN-t az Európai Parlamentben már 2004 óta képviselő Marine Le Pen 2011-ben vette át apjától a párt vezetését (Soós és Várnagy, 2020), a 2004-2006 között, majd 2009-től újra EP-képviselő Salvini a 2013-as választási kudarc és a Bossi család bukása után vette át az LN irányítását (Nábelek, 2020). A 2014-es választási győzelem során mandátumhoz jutott - Marion Maréchal-Le Pen kivételével - az FN akkoriban meghatározó valamennyi politikusa (pl. korábbi főtitkár, Louis Aliot - Marine Le Pen élettársa - és Florian Phillipot, a párt stratégiájáért felelős alelnök). Bár az EPben újonc volt, mégis az ENF frakció meghatározó tagjai közé tartozott Harald Vilimsky, az Osztrák Szabadságpárt főtitkára (Horaczek és Reiterer, 2009, 122-124. 0.). Le Pentől és Salvinitól eltérően, az otthoni fiatalítás miatt lett EP-képviselő a már említett Gerolf Annemans, a belga VB egyik legtapasztaltabb politikusa (1987-2012 között alsóházi frakcióvezető, 2012-2014-ben pártelnök), aki később a MENF/ID Party elnöke lett. 2017 és 2018 választásai során azonban a legtöbb vezető (pl. Le Pen, Aliot, Salvini, Fontana) hazatért a nemzeti politikai arénába.

Az ID frakcióból Annemans és Vilimsky mellett Jörg Meuthen, az AfD társelnöke emelhető ki a politikai tapasztalat szempontjából, illetve említést érdemel még az Igaz Finnektôl Laura Huhtasaari, aki a pártja jelöltjeként a 2018-as finn elnökválasztáson is indult (6,9 százalékkal a nyolc jelölt közül a harmadik helyen végzett).

A legnépesebb delegációk inkább a pártok másod- és harmadvonalából rekrutálódtak. Többségük helyi, regionális szinten szerzett politikai tapasztalattal rendelkezik. Sokan nemzeti parlamenti tagság nélkül váltak EP-képviselővé 2019-ben. A kisebb képviselettel rendelkező pártok ezzel ellentétes stratégiát követtek: tagjaik döntő többsége klasszikus pártkarrier és több szinten szerzett tapasztalat után jutott EP-mandátumhoz.

2019 óta a két nagy delegációban (Liga és RN) jelentős számban vannak jelen a pártvezetők olyan bizalmi emberei, akik korábban a személyes munkatársaik voltak, esetleg egyéb személyes kapcsolatot ápoltak velük, vagy más pártokat hátrahagyva csatlakoztak a radikális jobboldalhoz. Így lett EP-képviselő Salvini korábbi személyi asszisztense (Alessandro Panza), Le Pen kabinetfőnöke (Catherine Griset) és jogi képviselője (Gilbert Collard), valamint az idősebbik nővérének a férje (Philippe Olivier). Az RN három képviselője (Jean-Paul Garraud, Thierry Mariani, Jérôme Riviére) korábban az Unió egy Népi Mozgalomért (Union pour un mouvement populaire, UMP) nemzetgyúlési képviselője volt, a Liga pedig szintén mandátumhoz juttatott más jobboldali pártokból érkezőket (pl. Anna Bonfrisco, Lucia Vuolo), de a frakcióvezető, Marco Zanni is az 5 Csillag Mozgalomból lépett át 2017-ben. 


\section{4. táblázat ${ }^{5}$}

Az ID frakció 2019-ben megválasztott képviselőinek a politikai tapasztalata

\begin{tabular}{|l|c|c|c|c|c|c|c|c|c|}
\hline & $\begin{array}{c}\text { Liga } \\
(\mathrm{N}=28)\end{array}$ & $\begin{array}{c}\mathrm{RN} \\
(\mathrm{N}=22)\end{array}$ & $\begin{array}{c}\text { AfD } \\
(\mathrm{N}=11)\end{array}$ & $\begin{array}{c}\text { VB } \\
(\mathrm{N}=3)\end{array}$ & $\begin{array}{c}\text { FPÖ } \\
(\mathrm{N}=3)\end{array}$ & $\begin{array}{c}\text { PS } \\
(\mathrm{N}=2)\end{array}$ & $\begin{array}{c}\text { SPD } \\
(\mathrm{N}=2)\end{array}$ & $\begin{array}{c}\text { EKRE } \\
(\mathrm{N}=1)\end{array}$ & $\begin{array}{c}\text { DF } \\
(\mathrm{N}=1)\end{array}$ \\
\hline Miniszter & 0 & 1 & 0 & 0 & 0 & 0 & 1 & 0 & 0 \\
\hline $\begin{array}{l}\text { Tagállami } \\
\text { képviselő } \\
\text { (alsóház) }\end{array}$ & 0 & 5 & 0 & 2 & 2 & 2 & 1 & 1 & 1 \\
\hline $\begin{array}{l}\text { Tagállami } \\
\text { képviselő } \\
\text { (felsőház) }\end{array}$ & 1 & 0 & 0 & 0 & 1 & - & 0 & - & - \\
\hline $\begin{array}{l}\text { EP- } \\
\text { képviselő }\end{array}$ & 4 & 6 & 1 & 1 & 2 & 0 & 0 & 0 & 0 \\
\hline $\begin{array}{l}\text { Regionális/ } \\
\text { megyei } \\
\text { képviselő }\end{array}$ & 7 & 14 & 1 & 2 & 1 & 0 & 1 & 0 & 1 \\
\hline $\begin{array}{l}\text { Önkor- } \\
\text { mányzati } \\
\text { képviselő }\end{array}$ & 14 & 10 & 3 & 2 & 3 & 2 & 1 & 1 & 1 \\
\hline
\end{tabular}

Jelentős újdonságnak tekinthető, hogy az ID frakcióban korábbi kormánytagok is megjelentek radikális jobboldali politikusként. Thierry Mariani (RN) 2010-2012 között az UMP politikusaként volt a francia kormány közlekedési minisztere, az egykori kórházigazgató, a cseh Ivan David (SPD) pedig szociáldemokrata politikusként volt egészségügyi miniszter 1998-1999-ben. A jelenlétük arra hívja fel a figyelmet, hogy a szuverenista, euroszkeptikus politikusok egyre nagyobb számban szorulnak ki a mainstream pártokból, ami vagy önálló párt alapítására, vagy más szereplőkhöz történő csatlakozásra ösztönzi őket. A radikális jobboldali pártok erősödésének újabb hulláma lehetőséget kínál nekik arra, hogy visszatérjenek a politika élvonalába, míg e pártoknak a politikai centrum irányába történő nyitási, szavazatszerzési kísérletébe (Akkerman, De Lange és Rooduijn, 2016) jól illeszkedik a kormányzati tapasztalattal rendelkező személyek befogadása, pozícióhoz juttatása.

5 A táblázat azt tartalmazza, hogy a képviselők milyen szinten rendelkeztek korábban politikai tisztséggel; aki több pozíciót is betöltött, az több helyen is szerepel. Harald Vilimsky például az FPÖ jelöltjeként önkormányzati (2001-2005), felsőházi (2005-2006) és alsóházi képviselő (2006-2014) is volt, mielőtt 2014-ben EP-mandátumot szerzett volna. Forrás: European Parliament, 2020 és az érintett pártok honlapja. 


\section{Külügyi Szemle}

A gender gap megszúnése

A 2000-es években a szakirodalom általánosan elfogadott álítása volt, hogy a radikális jobboldali pártokban a nők aránya minden szinten (vezetők, képviselők, párttagok, szavazók) alacsonyabb, mint a férfiaké (Givens, 2004; Norris, 2005, 144-148. 0.; Mudde, 2007, 113-117. o.). Ez azonban már az ENF frakcióra sem volt igaz; a női politikusok aránya a radikális jobboldalon is fokozatosan közelített az EP átlagához (Hajdú, 2017a, 77. o.), az ENF-en, majd az ID-n belüli is gyakorlatilag megegyezett az intézményi átlaggal (5. táblázat). A két legnépesebb delegáció közül a Ligában a nők voltak többségben (15:13 arányban), az RN delegációjában pedig egyenlően oszlott meg a két nem. A gender gap megszúnése melletti további érv, hogy - a 2015-2019 közötti időszakhoz hasonlóan (Hajdú, 2017a, 77. o.) - a nói képviselők aránya az ID esetében (39,7\%) magasabb, mint az EPP (34,1\%) és az ECR frakcióéban (30,6\%) volt 2019-ben.

5. táblázat ${ }^{6}$

A női képviselők aránya a radikális jobboldali képviselőcsoportokban

\begin{tabular}{|l|c|c|c|c|c|}
\hline Nói képviselök & $\begin{array}{c}\text { ER } \\
1984 \\
(\mathrm{~N}=16)\end{array}$ & $\begin{array}{c}\mathrm{DR} \\
1989 \\
(\mathrm{~N}=17)\end{array}$ & $\begin{array}{c}\text { ITS } \\
2007 \\
(\mathrm{~N}=20)\end{array}$ & $\begin{array}{c}\text { ENF } \\
2015 \\
(\mathrm{~N}=38)\end{array}$ & $\begin{array}{c}\text { ID } \\
(\mathrm{N}=73)\end{array}$ \\
\hline Száma & 1 & 2 & 5 & 13 & 29 \\
\hline Aránya & $6,3 \%$ & $11,8 \%$ & $25,0 \%$ & $35,1 \%$ & $39,7 \%$ \\
\hline EP-arány & $17,7 \%$ & $19,3 \%$ & $30,2 \%$ & $36,9 \%$ & $40,4 \%$ \\
\hline
\end{tabular}

Az átlagéletkor további csökkenése

Az 1984 és 1994 között múködött radikális jobboldali frakciók átlagéletkora jelentősen magasabb volt az utóbbi ciklusok tagjaiénál. Az alapítók, a "frontharcosok" generációja az ENF megalakulására szinte teljesen eltúnt (Hajdú, 2017a, 78-79. o.), az utolsó képviselőik (pl. Jean-Marie Le Pen) is veszítettek az utódlási küzdelemben (Soós és Várnagy, 2020). Bár az új Európai Parlament megalakulásakor az ID átlagéletkora kissé meghaladta az intézményi értékét, a radikális jobboldali képviselők esetében a csökkenés mégis folytatódott, Marco Zanni pedig az EP történetének az egyik legfiatalabb frakcióvezetője lett.

6 Forrás: European Parliament, 2020; European Parliament Research Service Blog, 2019. 


\section{6. táblázat ${ }^{7}$}

Az átlagéletkor alakulása a radikális jobboldali frakciók esetében

\begin{tabular}{|c|c|c|c|c|c|}
\hline Korcsoport & $\begin{array}{c}\text { ER } \\
1984 \\
(\mathrm{~N}=16)\end{array}$ & $\begin{array}{c}\text { DR } \\
1989 \\
(\mathrm{~N}=17)\end{array}$ & $\begin{array}{c}\text { ITS } \\
2007 \\
(\mathrm{~N}=20)\end{array}$ & $\begin{array}{c}\text { ENF } \\
2015 \\
(\mathrm{~N}=38)\end{array}$ & $\begin{array}{c}\text { ID } \\
2019 \\
(\mathrm{~N}=73)\end{array}$ \\
\hline-30 év & 0 & 0 & 1 & 1 & 3 \\
\hline $31-40$ év & 3 & 3 & 1 & 3 & 14 \\
\hline $41-50$ év & 6 & 4 & 6 & 16 & 18 \\
\hline $51-60$ év & 3 & 4 & 5 & 10 & 23 \\
\hline $61-70$ év & 2 & 5 & 5 & 8 & 14 \\
\hline $71-$ év & 2 & 1 & 2 & 0 & 1 \\
\hline Atlagéletkor & 55,8 & 54,0 & 53,9 & 51,0 & 50,2 \\
\hline Frakcióvezető életkora & 56 & 61 & 56 & $46(\mathrm{MLP})$ & 32 \\
\hline EP átlagéletkora & 48,3 & 47,9 & 49,1 & $53(\mathrm{MdG})^{*}$ & 33,0 \\
\hline
\end{tabular}

*Miljøpartiet De Grønne (a norvég Zöld Párt).

\section{Az Identitás és Demokrácia frakció jelentősége}

Az ID frakció a radikális jobboldali pártok eddigi legnagyobb és legszervezettebb együttmúködési formája. Úgy túnik, a korábban akadályozó tényezőnek tekintett ideológiai, stratégiai ellentétek és történelmi sérelmek egyre kevésbé jelentenek gátló tényezőt az ilyen típusú pártok kooperációja szempontjából. A gazdaságpolitikai kérdések sem jelentenek törést a protekcionista RN és az alapítók piacpárti elkötelezettségét továbbra is képviselő AfD között. A társadalompolitikai kérdésekben konzervatív FPÖ, EKRE és PS megfér a szexuális kisebbségeket érő támadások szankcionálásának szigorításáért kampányoló PVV és az azonos nemúek házasságát - heves belső konfliktusok után - elfogadó RN mellett. A kelet-nyugati, régi-új tagállami szembenállás sem befolyásolja érdemben a radikális jobboldali frakciók tagjainak a körét. Az ID jelentős részének (pl. RN, Liga, AfD, FPÖ) oroszbarát külpolitikai irányvonala sem bírt olyan erővel, amely megakadályozta volna az oroszokkal szemben kritikus észt és finn radikálisok, illetve az Amerika- és Izrael-barát PVV csatlakozását. A hazájukban kormányon lévő pártok (FPÖ, Liga, EKRE) is az ENF, majd az ID frakció tagjai maradtak, annak ellenére, hogy a koalíciós partnereik a kilépést javasolták nekik. A frakcióhoz olyanok is csatlakoztak (DF, PS), amelyek korábban a hazai szövetségi lehetőségeiket többre értékelték az ideológiai szempontból hasonló pártok európai társaságánál (Hajdú, 2020).

Az érintett pártok nem csupán program, retorikai elemek és stílus szempontjából igazodtak az európai mintázatokhoz. A globalizáció és az európai integráció kritikusai épp azokat az együttmúködési mintákat kezdték követni, azokat az eszközöket használni, amelyek az általuk korábban bírált folyamatokba illeszkednek. Európai szintú struktúrákat építettek fel, amelyek szervesen kapcsolódnak az EU intézményrendszeréhez.

7 Forrás: European Parliament, 2020; Hajdú, $2017 a$. 


\section{Külügyi Szemle}

E stratégia részét képezi az EP-frakció, valamint az europárt múködtetése is. A folyamatot jól illusztrálja, hogy az ID frakció alakuló ülésén részt vett több olyan pártelnök (Marine Le Pen, RN; Jussi Halla-aho, PS; Tomio Okamura, SPD) is, akik akkor nem rendelkeztek EP-mandátummal.

Bár az utóbbi években komoly előrelépések figyelhetőek meg a radikális jobboldali pártok együttmúködése szempontjából, egy olyan kiterjedt és erős szervezeti, intézményi háttér felépítése, amilyen az EPP esetében megvalósult, továbbra is erősen kérdésesnek túnik. A stratégiai különbségek (pl. a spanyol Vox reménykedése a kormányra kerülésben) és személyes rivalizálás (pl. Farage és a Brexit Party) végül 2019-ben is meghiúsította egy nagy, egységes euroszkeptikus frakció létrehozását, valamint azt is, hogy az Identitás és Demokrácia képviselőcsoport létszáma átlépje a 100 főt. Bármennyire is törekednek a kormányzati tapasztalattal rendelkező pártok megszólítására, a hazai pártrendszerben az FPÖ és a Liga ismételt ellenzékbe kerülése, valamint több szereplőnek a továbbra is elszigetelt helyzete (pl. AfD, VB) az ID vonatkozásában jelentős hátránynak tekinthető a kormányzati szerepben lévő pártok sokaságát összefogó EPP és ECR frakcióval szemben.

Ennek tükrében felmerül a kérdés, hogy az ID frakció csupán a radikális jobboldal szintlépésének tekinthetô-e, vagy az európai pártrendszerek átalakulását kísérő átmeneti állapotnak. A korábbi ciklusokban az EPP-től jobbra sokszínú, gyorsan változó, instabil konzervatív és euroszkeptikus frakciók múködtek (Wagner, 2011). 2009-tôl azonban fokozatos stabilizálódás figyelhető meg az Európai Parlamentben. A brit konzervatívok kezdeményezésére létrejött az Európai Konzervatívok és Reformerek (European Conservatives and Reformists, ECR) képviselőcsoport (Steven, 2016), amely "túlélte" ugyan a brexitet, azonban a létszáma a 2019-es választáson már a radikális jobboldali, újnacionalista pártokat tömörítő ID-é alá csökkent. A brexit következtében ráadásul távoztak az intézményből azon euroszkeptikus képviselők is, akikre - akár egyénenként is - az alapításhoz szükséges minimális létszám eléréséhez bármely heterogén euroszkeptikus és elitellenes frakciónak (pl. EFDD 2014-2019) számítania lehetett.

Az Európai Parlament jobboldalán tapasztalható átrendeződés természetesen öszszefügg a nemzeti színtéren zajló változásokkal. A korábban domináns helyzetben lévő kereszténydemokrata (pl. CDU, CDA) vagy a helyi baloldallal rivalizáló blokkot vezető pártok (pl. a svéd MP, a dán Venstre) új bevándorlás- és elitellenes kihívókkal szembesültek, amelyek az utóbbi évtizedek során alapjaiban változtatták meg az európai pártrendszereket (Bale és Krouwel, 2013; Mudde, 2014a). A radikális jobboldali pártok már olyan országokban (pl. Németország, Spanyolország) is kiemelkedő sikereket értek el, ahol a szakirodalom korábban kizárta a megjelenésüket és a tartósan magas támogatottságukat. További fontos változás, hogy - a speciális helyzetben lévő Svájci Néppárt kivételével - csak elvétve és egy-egy választásra váltak a nem baloldali blokk legerősebb szereplőjévé (pl. Ausztria, Dánia, Norvégia), 2014 óta azonban egyre többjük 
tudta elérni ezt a pozíciót. Az FN/RN 2014-ben és 2019-ben is megnyerte az EP-választást, Marine Le Pen pedig 2017-ben megelőzte a jobboldali jelölteket. A Liga 2018-ban a jobboldal legerősebb pártjává vált, 2019-ben EP-választást nyert. Azok az EU-tagállamokban múködő pártok, amelyek ezt a szintet korábban szintén el tudták érni (pl. FPÖ, DF, PS) ugyancsak az ID frakcióhoz tartoznak. Mindez arra utal, hogy egy új politikai tömb szerveződik, amely számos kérdésben a mainstream elittel szemben, a nemzeti szuverenitás kérdésének a középpontba helyezésével határozza meg önmagát. Ennek következtében határozottan elválik, sőt egyre markánsabban szembefordul az európai politikai életet meghatározó, konszenzusosnak tekintett alapállításokkal - legyen szó akár a migrációnak és az állampolgárságnak, akár az európai integrációnak vagy a gazdasági élet szervezésének a kérdéseiről, a válaszaikat a nemzeti szuverenitásra vonatkozó állásfoglalásuk határozza meg (Hajdú, 2020).

A nemzeti szuverenitást érő kihívásokra, különösen az európai integrációnak az azt korlátozó hatására, a migrációra és a gazdasági globalizációra szinte minden európai párt megfogalmaz valamilyen véleményt. A politikai elit homogenizációja miatt azonban a politikai gondolkodás és cselekvés területén egyaránt az az álláspont a domináns, amely szerint - éppen a kihívások komplexitása miatt - a nemzetállami megoldásoknak önmagukban nincs esélyük érdemi változások elérésére, sőt az önálló nemzeti utak csak további konfliktusokat generálnak. Az integráció hívei szerint az együttműködés, az összefonódás nem csupán hatékonyabb intézkedéseket tesz lehetővé, hanem egyúttal csökkenti a nemzeti öncélú lépéseket és az azokból keletkező problémákat. A második világháború után erre vonatkozóan kialakult európai konszenzus azonban eltűnőben, felbomló fázisban van. Az ID frakció ennek az átalakulási folyamatnak a részét képezi, így a jelenlegi formájában nagy valószínúséggel csak egy átmeneti politikai formáció az európai politikában.

\section{Összegzés}

Az ID frakció létrejötte a radikális jobboldali együttmúködés kiterjedése és intézményesülése szempontjából újabb fontos állomásnak tekinthető. Eddig csupán az 1984-1989 és 1989-1994 közötti időszakban történt meg, hogy egymást követő két ciklusban is létezett egy radikális jobboldali frakció, amelyek tagsága azonban kizárólag az FN-ben egyezett meg. 2019-ben egy, a korábbi tagságára is építő, egyúttal kibővült frakció jött létre, amely újabb jele az európai politikai és pártrendszerek átalakulásának.

A kezdeti formációknak az 1980-as és 1990-es évek során (ER frakció, EuroNat europárt) az új szereplők stabilizálódásában, a nemzetközi kapcsolataik kialakításában volt szerepük, amely kapcsolatrendszerbe a 2007-es ITS frakció formálisan is bekapcsolta a kormányzati periódusban meggyengült FPÖ-t és az új tagállamok néhány pártját (Ataka, PRM). Ezt az együttműködést az ENF frakció tovább bővítette 


\section{Külügyi Szemle}

a Jean-Marie Le Pen féle FN-t még határozottan elutasító liberálisabb (PVV), illetve a nemzeti politikai verseny nem elszigetelt, kormányzati tapasztalattal rendelkező (Liga) pártokkal. A 2010-es években a radikális jobboldali együttmúködés a korábban sok tekintetben az intézményi elemek által kikényszerített kooperációból tudatos stratégiává vált. 2019-ben ez eredményezte újabb pártok bekapcsolódását és a frakció további növekedését. Az ID keretében egy olyan politikai szövetség formálódik, amelynek tagjai egyre markánsabban fordulnak szembe az európai politikai életet meghatározó, konszenzusosnak tekintett alapállításokkal például a migráció, az európai integráció vagy az állam szerepének és a gazdaság szervezésének a kérdésében.

A képviselőcsoport jövője annak a függvénye, hogy a nemzetállami keretek megítélésérôl zajló politikai vita milyen irányt vesz. Amennyiben a nemzetállami kompetenciák a jövőben erősödnek, akkor az ID frakció pártjai a korábbi pártrendszerek bomlásának a nyerteseivé válhatnak. Ha viszont az azok további leépítése melletti álláspont erősödik, akkor rövid távon az ID pártjaira az európai és a tagállami színtéren egyaránt fokozódó elszigeteltség vár. Ez utóbbi esetben is számolni kell az önálló pólusképzési erejükkel, ami viszont szintén más környezetet és jövőképet kínálna az ID frakció pártjainak.

\section{Irodalomjegyzék}

Akkerman, Tjitske, De Lange, Sarah L. és Rooduijn, Matthijs (2016). Inclusion and Mainstreaming? Radical Right-Wing Populist Parties in the New Millenium. In Akkerman, Tjitske, De Lange, Sarah L. és Rooduijn, Matthijs (szerk.). Radical RightWing Populist Parties in Western Europe. Into the Mainstream? Abingdon: Routledge (1-28. 0.).

Almeida, Dimitri (2010). Europeanized Euroscpetics? Radical Right Parties and European Integration. Perspectives on European Politics and Society, 17(4), 237-253.

Archick, Kristin és Mix, Derek E. (2011). The European Parliament. Current Politics and Economics of Europe, 23(2), 141-156.

Bale, Tim és Krouwel, André (2013). Down But Not Out: A Comparison of Germany's CDU/ CSU with Christian Democratic Parties in Austria, Belgium, Italy and the Netherlands. German Politics, 22(1-2), 16-45.

Brack, Nathalie (2013). Euroscepticism at the Supranational Level: The Case of the 'Untidy Right' in the European Parliament. Journal of Common Market Studies, 51(1), 85-104.

Dúró József (2020). Kormánypártból pária? Az Igaz Finnek. Kézirat.

Ennser, Laurenz (2012). The Homogeneity of West European Party Families: The Radical Right in Comapartive Perspectives. Party Politics, 18(2), 151-171.

European Parliament (2020). About Parliament. A letöltés ideje: 2020. május 12. https:// www.europarl.europa.eu/portal/en.

European Parliament Research Service Blog (2019). Members of the European Parliament, 2019-2024. A letöltés ideje: 2020. május 12. https://epthinktank. eu/2019/07/11/members-of-the-european-parliament-2019-2024/. 
Givens, Terri E. (2004). The Radical Right Gender Gap. Comparative Political Studies, $37(1), 30-54$.

Hajdú András (2017a). Európa nacionalistái egyesülhetnek? A radikális jobboldal képviselőcsoportjai az Európai Parlamentben. Politikatudományi Szemle, 26(2), 63-87.

Hajdú András (2017b). Generációváltás a radikális jobboldalon? A francia Nemzeti Front és a Flamand Érdek elitjének összehasonlítása. Politikatudomány Online, (4).

Hajdú András (2020). Radikális jobboldal és új nacionalizmus. Budapesti Corvinus Egyetem Politikatudományi Doktori Iskola, értekezéstervezet.

Hix, Simon, Noury, Abdul G. és Roland, Gérard (2007). Democratic Politics in the European Parliament. Cambridge: Cambridge University Press.

Horaczek, Claudia és Reiterer, Nina (2009). HC Strache. Bécs: Carl Ueberreuter GmbH.

Ladrech, Robert (2012). Party Change and Europeanisation: Elements of an Integrated Approach. West European Politics, 35(3), 574-588.

Mudde, Cas (2000). The Ideology of the Extreme Right. Manchester: Manchester University Press.

Mudde, Cas (2007). Populist Radical Right Parties in Europe. Cambridge: Cambridge University Press.

Mudde, Cas (2014a). The Le Pen-Wilders Alliance and the European Parliament: Plus ça change, plus la meme chose. The Washington Post. A letöltés ideje: 2020. május 11. http://www.washingtonpost.com/blogs/monkey-cage/wp/2014/02/11/the-lepen-wilders-alliance-and-the-european-parliament-plusca-change-plus-cest-lamemel.

Mudde, Cas (2014b). Fighting the System? Populist Radical Right Parties and Party System Change. Party Politics, 20(2), 217-226.

Nábelek Fruzsina (2020). Padániától az olasz identitás védelméig: az (Északi) Liga nemzeti párttá válása. Kézirat.

Norris, Pippa (2005). Radical Right: Voters and Parties in the Electoral Market. Cambridge: Cambridge University Press.

Polgár Tamás (2011). Az adóellenes neoliberalizmustól az idegenellenes nemzeti konzervativizmusig. A Dán Néppárt felemelkedésének története. In Lánczi András (szerk.). Nemzet és radikalizmus. Egy új pártcsalád felemelkedése. Budapest: Századvég Kiadó (93-116. o.).

Soós Eszter Petronella és Várnagy Réka (2020). Egy párt évtizedeken átivelő mérséklődési kísérlete: a francia Nemzeti Front. Kézirat.

Startin, Nicholas (2010). Where to for the Radical Right in the European Parliament? The Rise and Fall of Transnational Political Cooperation. Perspectives on European Politics and Society, 17(4), 429-449.

Steven, Martin (2016). 'Euro-Realism' in the 2014 European Parliament Elections: The European Conservatives and Reformists (ECR) and the Democratic Deficit. Journal of Representative Democracy, 52(1), 1-12.

Von Beyme, Klaus (2019). Rightwing Populism. An Element of Neodemocracy. Berlin: Springer Verlag.

Wagner, Markus (2011). The Right in the European Parliament Since 1979. Perspectives on European Politics and Society, 12(1), 52-67. 